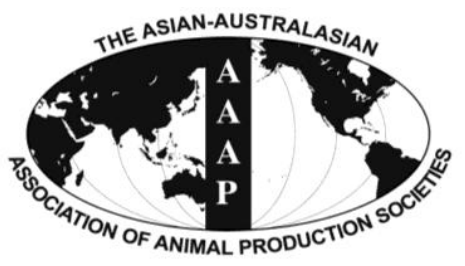

Asian Australas. J. Anim. Sci.

Vol. 26, No. 7 : 1047-1053 July 2013

http://dx.doi.org/10.5713/ajas.2013.13005

www.ajas.info

pISSN 1011-2367 elSSN 1976-5517

\title{
Comparison of Live Performance and Meat Quality Parameter of Cross Bred (Korean Native Black Pig and Landrace) Pigs with Different Coat Colors
}

\author{
S. J. Hur ${ }^{1}$, T. C. Jeong ${ }^{2,3}$, G. D. Kim ${ }^{4}$, J. Y. Jeong ${ }^{2,3}$, I. C. Cho ${ }^{5}$, H. T. Lim $^{2,3}$, B. W. Kim ${ }^{6}$, and S. T. Joo ${ }^{2,3, *}$ \\ ${ }^{1}$ Department of Bioresources and Food Science, Konkuk University, Seoul 143-701, Korea
}

\begin{abstract}
Five hundred and forty crossbred (Korean native black pig $\times$ Landrace) $\mathrm{F}_{2}$ were selected at a commercial pig farm and then divided into six different coat color groups: (A: Black, B: White, C: Red, D: White spot in black, E: Black spot in white, F: Black spot in red). Birth weight, 21st d weight, 140th d weight and carcass weight varied among the different coat color groups. D group (white spot in black coat) showed a significantly higher body weight at each weigh (birth weight, 140th d weight and carcass weight) than did the other groups, whereas the $\mathrm{C}$ group (red coat color) showed a significantly lower body weight at finishing stage (140th $\mathrm{d}$ weight and carcass weight) compared to other groups. Meat quality characteristics, shear force, cooking loss and meat color were not significantly different among the different coat color groups, whereas drip loss was significantly higher in $\mathrm{F}$ than in other groups. Most blood characteristics were not significantly different among the different groups, except for the red blood cells. (Key Words: Carcass Weight, Muscle Fiber Characteristics, Crossbred Pig, Pork Quality)
\end{abstract}

\section{INTRODUCTION}

The Korean native black pig (KNP, Sus scrofa coreanus) is a typical pig breed in Korea. The KNP have black glossy hairs, a caved face, big eyes, long straight noses, straightly upright ears, round shoulders, a narrow rear back and small body weight. Usually, KNP shows slower growth rate and lighter carcass weight than commercial pig breed which is a hybrid of Landracex Yorkshire $\times$ Duroc. Since early 20 th century, the population of KNP has been drastically decreased, due to their low productivity and poor genetic traits (when compared with

\footnotetext{
* Corresponding Author: S. T. Joo. Tel: +82-55-772-1943, Fax: +82-55-772-1949, E-mail: stjoo@gnu.ac.kr

${ }^{2}$ Department of Animal Science, Gyeongsang National University, Jinju 660-701, Korea.

${ }^{3}$ Institute of Agriculture and Life Science, Gyeongsang National University, Jinju 660-701, Korea.

${ }^{4}$ Division of Biotechnology, College of Applied Life Sciences, Jeju National University, 66 Jejudaehakro, Jeju 690-756, Korea.

5 National Institute of Animal Science, Rural Development Administration, Suwon 441-706, Korea.

${ }^{6}$ Department of Animal Science, College of Natural Resources \& Life Science, Pusan National University, Miryang 627-706, Korea.

Submitted Jan. 2, 2013; Accepted Jan. 7, 2013; Revised Apr. 2, 2013
}

the commercial imported breeds) (Kim et al., 2002), although meat from KNP is highly appreciated by Korean consumers because it has high redness and intramuscular fat content compared with commercial pig breeds. They believe that the juiciness and flavor of KNP pork is better than commercial breed pork such as Landrace, Yorkshire and Duroc. Moreover, consumers have preferred black coat color than white coat color in pigs. Therefore, KNP pork has been regarded as the most expensive and high-quality pork in Korea and so a genetic bleeding program for development of black pigs is highly recommended. As a consequence of the popularity of KNP, many have been crossbred with the commercial foreign breeds for upgrading their economic traits, such as body weight, fat traits, fecundity, and so forth (Kim et al., 2002). In general, there are large variations in coat colors and carcass traits (carcass weight and back fat thickness), and quality traits of meat from crossbred pigs. However, there is still a relatively poor understanding of quantity and quality traits in KNP and Landrace crossbred pigs. Moreover, there are no reports on the effect of coat colors on meat qualities of KNP and Landrace crossbred pigs by hybrid generation, although a few reports on genetic characteristics exist (Kim et al., 2002; Jeon et al., 2003; Kim et al., 2005; Han et al., 2008). This study was carried out to investigate the relationship 
between meat quality characteristics and the color of the coat of $\mathrm{KNP} \times$ Landrace crossbred pigs.

\section{MATERIALS AND METHODS}

\section{Animal}

Five hundred forty crossbred $(\mathrm{KNP} \times$ Landrace $) \mathrm{F}_{2}$ were selected at a commercial swine farm and then divided into six coat color groups (25 pigs/each group) as shown in Figure 1 (A: Black, B: White, C: Red, D: White spot in black, E: Black spot in white, F: Black spot in red). Body weight was measured at birthday, weaning day (21st d), 140th $\mathrm{d}$ and slaughtering day. Backfat thickness were measured at the 4-5th thoracic vertebra. Muscle samples were taken for histochemical analysis within $1 \mathrm{~h}$ postmortem and frozen in isopentane chilled with liquid nitrogen, according to the method proposed by Dubowitz and Brooke (1973). After $24 \mathrm{~h}$ chilling of carcasses, longissimus dorsi (LD) muscles were taken to evaluate meat quality traits, such as shear force, cooking loss, drip loss, fatty acid composition and meat color (CIE L*, a* and $\mathrm{b}^{*}$ ). Blood samples were collected by a jugular cannula at $12 \mathrm{~h}$ prior to slaughter.

\section{Chemical compositions}

Chemical compositions were determined using AOAC method (1995). Moisture was determined by oven-drying method at $110^{\circ} \mathrm{C}$ for $24 \mathrm{~h}$; for cooked samples total water content was calculated as (100-(total protein+total lipid+ total ash)). Total protein content was determined by the Kjeldahl method. The crude fat was extracted from $3 \mathrm{~g}$ of the meat sample using the procedure of Folch et al. (1957) with some modification. Three grams of meat sample was homogenized with $30 \mathrm{ml}$ of folch solution I (chloroform: methanol, 2:1, v/v) and homogenized with a Polytron homogenizer (IKA Labortechnik T25-B, Staufen, Germany) for $30 \mathrm{~s}$. The homogenate was filtered with Whatman No.1 filter paper in a $100 \mathrm{ml}$ measuring cylinder after stirring for $2 \mathrm{~h}$ at $4^{\circ} \mathrm{C}$. The filtered solution was stirred with $0.88 \%$ of $\mathrm{NaCl}$ (25\% volume of the filtered solution), and then allowed to separate into two layers for $1 \mathrm{~h}$ at room temperature. After washing the wall of measuring cylinder with $10 \mathrm{ml}$ of folch solution II (chloroform: methanol: $\mathrm{H}_{2} \mathrm{O}$ $=3: 47: 50$ ), the final volume of the lower layer was recorded The upper layer (methanol and water layer) was removed using an aspirator, and $10 \mathrm{ml}$ of the lower layer (chloroform containing lipid extracts) was taken in a dish to dry at $50^{\circ} \mathrm{C}$. The weight of dish was measured before and after drying, and the fat content was calculated using the following equation: Fat content $(\%)=(((c-b) \times a / 10) /$ grams of sample) $\times 100$, where $\mathrm{a}=$ the final volume of the lower layer, $\mathrm{b}=$ weight of dish before drying, and $\mathrm{c}=$ weight of dish after drying. Ash was determined as the remnant weight after calcination of a $2 \mathrm{~g}$ sample at $550^{\circ} \mathrm{C}$ for $4 \mathrm{~h}$.

\section{Shear force}

Warner-Bratzler shear force (WBSF) values were determined using an Instron Universal Testing Machine (Model 4400, Instron Corp., MA, USA). Samples were 1.3$\mathrm{cm}$ diameter cores obtained from steaks cooked to $70^{\circ} \mathrm{C}$ internal temperature for $30 \mathrm{~min}$.

\section{Cooking loss}

To determine cooking loss, $2.5 \mathrm{~cm}$ thick (approximately

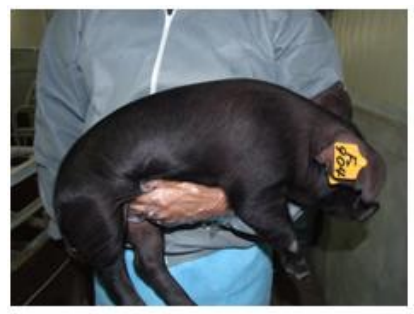

A

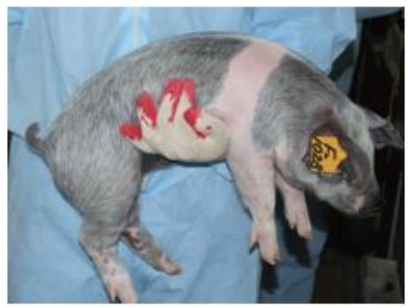

$\mathrm{D}$

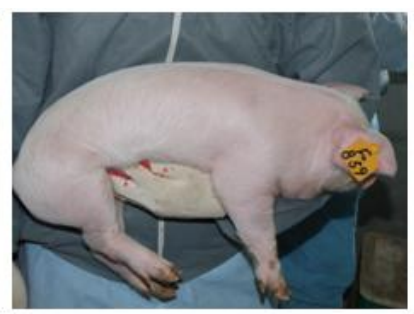

B

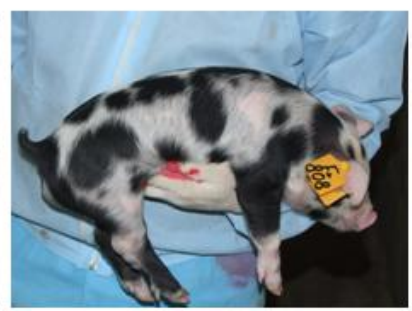

E

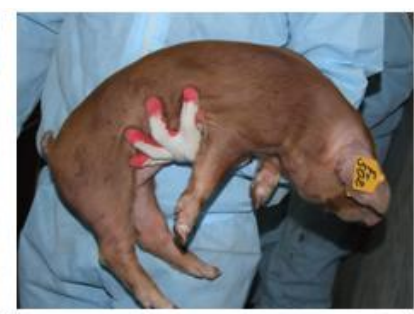

$\mathrm{C}$

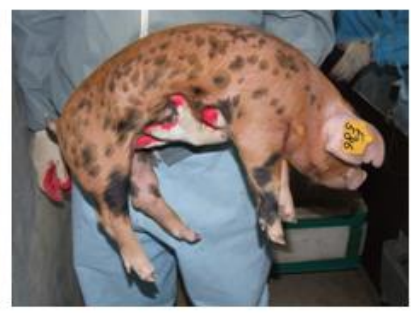

$\mathbf{F}$

Figure 1. The different coat colors in crossbred pig $(\mathrm{KNP} \times$ Landrace $) \mathrm{F}_{2}$. 
$150 \mathrm{~g})$ sliced loin samples was placed plastic zipper bags and cooked to an internal temperature of $70^{\circ} \mathrm{C}$ in water bath. Cooking loss was determined by weight difference between uncooked and cooked samples. Calculation was: Cooking loss $(\%)=$ before cooking weight $(\mathrm{g})$-after cooking weight $(\mathrm{g}) /$ before cooking weight $(\mathrm{g}) \times 100$

\section{Drip loss}

Drip loss was determined using a hanging method. Two $2.5 \mathrm{~cm}$ thick (approximately $150 \mathrm{~g}$ ) slices were taken from the loin and hung in an airtight plastic container $(18 \times 14 \times 10)$ at $4{ }^{\circ} \mathrm{C}$. The amount of drip was measured as the loss in weight of the slice after $48 \mathrm{~h}$, and was expressed as a percentage of the initial weight. Calculation was: Drip loss $(\%)=$ before hanging weight $(\mathrm{g})$-after hanging weight $(\mathrm{g}) /$ before hanging weight $(\mathrm{g}) \times 100$.

\section{Fatty acid composition}

For fatty acid composition, lipids were extracted with chloroform and methanol as described by Folch et al. (1957). For lipid hydrolysis, an aliquot of lipid extract (30 $\mathrm{mg}$ ) and $3 \mathrm{ml}$ of $4 \% \mathrm{H}_{2} \mathrm{SO}_{4}$ in methanol were combined in a screw-capped test tube. The test tube was placed in boiling water $\left(100^{\circ} \mathrm{C}\right)$ for $20 \mathrm{~min}$ and subsequently cooled at room temperature. The resulting free fatty acids were methylated with $1 \mathrm{ml}$ of $14 \%$ boron trifluoride in methanol at room temperature for $30 \mathrm{~min}$. Water $(1 \mathrm{ml})$ and hexane $(5 \mathrm{ml})$ were added. Samples were vortexed and centrifuged at 500 $\times \mathrm{g}$ for $10 \mathrm{~min}$. The upper organic solvent layer was used to determine fatty acids composition. Fatty acid methyl esters were analyzed on a gas chromatograph (Agilent Technologies 6890N, Santa clara, CA, USA) equipped with an on-column injection port and flame-ionization detector. A Silica capillary column (Omegawax 320, $30 \mathrm{~m} \times 0.32 \mathrm{~mm}$ $\times 0.25 \mu \mathrm{m}$ film; Supelco, Bellefonte, PA, USA) was used for the separation of the fatty acid methyl esters. The gas chromatography oven temperature was $140^{\circ} \mathrm{C}$, and increased at a rate of $2^{\circ} \mathrm{C} / \mathrm{min}$ to a final temperature of $230^{\circ} \mathrm{C}$. The temperatures of injector port and detector temperatures were set at $240^{\circ} \mathrm{C}$ and $250^{\circ} \mathrm{C}$, respectively. Fatty acid methyl ester $(1 \mu \mathrm{l})$ was injected onto the split injection port (100:1 split ratio). The flow rate for $\mathrm{He}$ carrier gas was $50 \mathrm{ml} / \mathrm{min}$. Each fatty acid was identified by its retention time.

\section{Meat color}

Meat color (CIE L*a*b*) was measured on a surface of muscles using a Minolta Chromameter CR-300 (Minolta Co., Tokyo, Japan) that was standardized with a white plate $(\mathrm{Y}=93.5, \mathrm{X}=0.3132, \mathrm{y}=0.3198)$.

\section{Histochemical characteristics}

Transverse serial sections of $10 \mu \mathrm{m}$ were cut from entire blocks $(1.0 \times 1.0 \times 1.5 \mathrm{~cm})$ on a cryostat microtom (HM525, Microm $\mathrm{GmbH}$, Germany) at $-27^{\circ} \mathrm{C}$ and subsequently incubated for histochemical demonstration of myosin adenosine triphosphatase (mATPase) following alkaline $(\mathrm{pH}$ 10.75) and acid ( $\mathrm{pH} 4.65)$ preincubation using a modified Brooke and Kaiser (1970) method. The stained sections were examined by an image analysis system (ImagePro ${ }^{\circledR}$ plus 5.1, Media Cybernetics Inc., MD, USA). The muscle fibers were divided into fiber type I, IIA and IIB according to the nomenclature of Brooke and Kaiser (1970). About 600 fibers per sample were counted to estimate the distribution and size of fiber types. Fiber number and area percentages, fiber diameter and density were determined. Fiber number percentage refers to the ratio of counted fiber numbers of each fiber type to the total counted fiber number and fiber area percentage was the ratio of the total crosssectional area of each fiber type to the total measured fiber area. The density of fibers was calculated using the mean number of fibers per $\mathrm{mm}^{2}$.

\section{Blood characteristics}

Fifteen $\mathrm{ml}$ blood samples were collected into ethylenediaminetetraacetic acid (EDTA) bottles by a jugular cannula at $12 \mathrm{~h}$ prior to slaughter and then stored in a cooler at 5 to $10^{\circ} \mathrm{C}$. Total protein, creatin phosphokinase, white blood cell, red blood cell, hemoglobin and globulin were analyzed by using a whole blood analyzer (VetScan, ABAXIS, CA, USA), and triglyceride and cholesterol were analyzed by using a serum analyzer (Vetabc, Scil, Viernheim, Germany) as specified by the manufacturer.

\section{Statistical analysis}

The experimental data were analyzed by the analysis of variance procedure of statistical analysis systems (SAS, 2002), and the Duncan's multiple range test was used to determine the significant differences among means at 5\% level of significance (SAS, 2002). Pearson correlation coefficients were determined to describe the relationship between muscle fiber characteristics and meat quality and carcass traits using partial correlation coefficients (SAS, 2002).

\section{RESULTS AND DISCUSSION}

\section{Carcass characteristics}

Body weight, carcass weight, backfat thickness and chemical compositions are presented in Table 1. As expected, birth weight, 21 st d weight, 140th d weight and carcass weight were significantly different among the different coat color groups. The D group (white spot in a black coat) showed significantly higher body weight, e.g. birth weight, 140th d weight and carcass weight, than did the other groups, whereas the $\mathrm{C}$ group (red coat ) showed a 
Table 1. Carcass characteristics and chemical compositions of crossbred pigs (KNP $\times$ Landrace) $\mathrm{F}_{2}$

\begin{tabular}{lcccccc}
\hline \multirow{2}{*}{ Measurements } & \multicolumn{7}{c}{ Coat color groups } \\
\cline { 2 - 7 } & $\mathrm{A}^{1}$ & $\mathrm{~B}$ & $\mathrm{C}$ & $\mathrm{D}$ & $\mathrm{E}$ & $\mathrm{F}$ \\
\hline Birth weight (kg) & $1.45 \pm 0.25^{\mathrm{B}}$ & $1.52 \pm 0.30^{\mathrm{B}}$ & $1.60 \pm 0.28^{\mathrm{AB}}$ & $1.71 \pm 0.27^{\mathrm{A}}$ & $1.52 \pm 0.13^{\mathrm{B}}$ & $1.42 \pm 0.12^{\mathrm{B}}$ \\
21st d weight (kg) & $6.30 \pm 0.52^{\mathrm{BC}}$ & $6.61 \pm 0.35^{\mathrm{BC}}$ & $7.48 \pm 0.17^{\mathrm{A}}$ & $6.78 \pm 0.22^{\mathrm{AB}}$ & $6.39 \pm 0.39^{\mathrm{BC}}$ & $5.79 \pm 0.16^{\mathrm{C}}$ \\
140th d weight (kg) & $69.67 \pm 0.83^{\mathrm{AB}}$ & $73.33 \pm 0.68^{\mathrm{A}}$ & $66.00 \pm 0.34^{\mathrm{B}}$ & $72.91 \pm 0.56^{\mathrm{A}}$ & $72.64 \pm 0.77^{\mathrm{A}}$ & $70.36 \pm 0.87^{\mathrm{AB}}$ \\
Carcass weight (kg) & $78.18 \pm 1.56^{\mathrm{A}}$ & $80.82 \pm 1.98^{\mathrm{A}}$ & $68.60 \pm 2.01^{\mathrm{B}}$ & $78.23 \pm 1.25^{\mathrm{A}}$ & $79.19 \pm 1.68^{\mathrm{A}}$ & $82.55 \pm 1.44^{\mathrm{A}}$ \\
Back fat thickness (mm) & $22.72 \pm 0.89^{\mathrm{AB}}$ & $23.66 \pm 0.47^{\mathrm{AB}}$ & $17.60 \pm 1.01^{\mathrm{C}}$ & $19.77 \pm 0.96^{\mathrm{BC}}$ & $23.11 \pm 0.45^{\mathrm{AB}}$ & $25.73 \pm 0.75^{\mathrm{A}}$ \\
Moisture (\%) & $73.73 \pm 2.13$ & $73.82 \pm 1.89$ & $74.25 \pm 3.21$ & $73.63 \pm 2.45$ & $74.03 \pm 3.10$ & $73.52 \pm 2.14$ \\
Crude protein (\%) & $22.03 \pm 2.32$ & $21.90 \pm 1.56$ & $21.75 \pm 0.78$ & $21.85 \pm 1.23$ & $21.97 \pm 2.35$ & $22.34 \pm 2.61$ \\
Crude fat (\%) & $3.22 \pm 0.78$ & $3.13 \pm 0.93$ & $2.91 \pm 0.81$ & $2.96 \pm 0.15$ & $2.77 \pm 0.96$ & $3.04 \pm 0.44$ \\
Ash & $1.02 \pm 0.02$ & $1.15 \pm 0.25$ & $1.09 \pm 0.87$ & $1.56 \pm 0.23$ & $1.23 \pm 0.41$ & $1.10 \pm 0.20$ \\
\hline
\end{tabular}

$\overline{\mathrm{A}, \mathrm{B}, \mathrm{C}}$ Means $( \pm \mathrm{SD})$ with different letters are significantly different $(\mathrm{p}<0.05)$.

${ }^{1}$ A: Black coat color, B: White coat color, C: Red coat color, D: White spot in black coat color, E: Black spot in white coat color, F: Black spot in red coat color. $\mathrm{N}=580$.

significantly lower body weight at the finishing stage (140th day weight and carcass weight) compared to other groups. We present the quality characteristics in Table 2 . In terms of meat quality characteristics, shear force, cooking loss and meat color were not significantly different among the different coat color groups, whereas drip loss was significantly higher in F than other groups. Sanude et al. (2004) reported that breed type and slaughter weight influence carcass and meat quality parameters in several ways, including the properties and structure of muscle and meat physiology. Huff and Parrish (1993) also suggested that within the same breed type, the most important intrinsic factors affecting meat quality are age, live weight and sex. However, other studies (Cisneros et al., 1996; Latorre et al., 2004; Piao et al., 2004; Correa et al., 2006) showed that the meat qualities were not affected by growth rate and slaughter weight. Moreover, Correa et al. (2006) suggested that pigs can be slaughtered at heavier weight without compromising carcass and meat quality. We also observed that body weight, carcass weight or back fat thickness are not related to the meat quality characteristics and blood parameters. In this regard, we assume that meat qualities are more closely related with marbling, WHC and color rather than body weight and carcass weight.

Cho et al. (2007) reported that the carcass weight of KNP ranged from 40.34 to $65.32 \mathrm{~kg}$, whereas the carcass weight of KNP and Landrace crossbred pigs $\mathrm{F}_{2}$ ranged from 68.60 to $82.55 \mathrm{~kg}$. This indicates that the carcass weight of KNP can be improved by crossbreeding with the Landrace race. However, this study indicated that carcass weights had no effect on the meat and blood characteristics. Chemical compositions were not significantly different among the different groups. In general, body weight is related to back fat thickness or intramuscular fat contents. In this study, back fat thickness was significantly lower in $\mathrm{C}$ group (red coat) than other groups. The back fat thickness may be influenced by body weight because the body weight was lower in the $\mathrm{C}$ group (red coat) than other groups. Back fat is normally used to predict the intramuscular fat contents in pigs. de Koning et al. (1999) found that intramuscular fat content increased when increased as the back fat thickness in pig increased. In our previous study, the carcass weight

Table 2. Quality characteristics of crossbred pigs $(\mathrm{KNP} \times$ Landrace $) \mathrm{F}_{2}$

\begin{tabular}{lcccccc}
\hline \multirow{2}{*}{ Measurements } & \multicolumn{5}{c}{ Coat color groups } \\
\cline { 2 - 7 } & \multicolumn{1}{c}{$\mathrm{A}^{1}$} & $\mathrm{~B}$ & $\mathrm{C}$ & $\mathrm{D}$ & $\mathrm{E}$ & $\mathrm{F}$ \\
\hline Shear force (kg) & $3.57 \pm 0.54$ & $3.60 \pm 0.98$ & $3.20 \pm 0.61$ & $3.47 \pm 0.48$ & $3.51 \pm 0.87$ & $3.63 \pm 0.90$ \\
Cooking loss (\%) & $35.53 \pm 2.23$ & $35.82 \pm 3.14$ & $38.67 \pm 1.27$ & $35.87 \pm 2.91$ & $35.77 \pm 2.30$ & $34.33 \pm 3.08$ \\
Drip loss (\%) & $2.11 \pm 0.23^{\mathrm{B}}$ & $2.06 \pm 0.15^{\mathrm{B}}$ & $2.28 \pm 0.24^{\mathrm{AB}}$ & $2.06 \pm 0.07^{\mathrm{B}}$ & $2.28 \pm 0.30^{\mathrm{AB}}$ & $3.23 \pm 0.41^{\mathrm{A}}$ \\
Saturated fatty acids (\%) & $40.75 \pm 2.45$ & $40.63 \pm 3.01$ & $40.28 \pm 2.87$ & $41.95 \pm 3.45$ & $40.81 \pm 1.23$ & $40.42 \pm 2.98$ \\
Unsaturated fatty acid (\%) & $59.25 \pm 1.85$ & $59.37 \pm 0.79$ & $59.72 \pm 2.13$ & $58.05 \pm 3.07$ & $59.19 \pm 2.65$ & $59.58 \pm 3.09$ \\
Meat color by meat grader & $4.09 \pm 1.12$ & $4.03 \pm 0.39$ & $4.25 \pm 0.87$ & $3.93 \pm 1.12$ & $4.02 \pm 0.96$ & $3.91 \pm 0.27$ \\
Color $\quad$ L $^{*}$ value & $48.58 \pm 1.45$ & $48.76 \pm 1.23$ & $49.94 \pm 2.08$ & $48.42 \pm 1.65$ & $49.56 \pm 2.00$ & $49.45 \pm 1.56$ \\
\multicolumn{1}{c}{$\mathrm{a}^{*}$ value } & $8.61 \pm 1.23$ & $8.42 \pm 1.45$ & $9.76 \pm 2.30$ & $7.68 \pm 0.21$ & $8.15 \pm 0.79$ & $8.21 \pm 1.10$ \\
\multicolumn{1}{c}{$\mathrm{b}^{*}$ value } & $3.30 \pm 0.24$ & $3.17 \pm 0.87$ & $3.86 \pm 0.39$ & $2.80 \pm 0.78$ & $3.26 \pm 1.23$ & $3.41 \pm 1.12$ \\
\hline
\end{tabular}

A,B Means $( \pm \mathrm{SD})$ with different letters are significantly different $(\mathrm{p}<0.05)$.

${ }^{1}$ A: Black coat color, B: White coat color, C: Red coat color, D: White spot in black coat color, E: Black spot in white coat color, F: Black spot in red coat color. $\mathrm{N}=580$. 
of crossbred pigs varied, from 75.40 to $104.40 \mathrm{~kg}$, and back fat thickness and intramuscular fat contents increased with increased as the body weight of crossbred pigs increased (unpublished data). These results agreed with Galián et al. (2009), who reported that heavier pigs showed higher intramuscular fat levels and darker color (lower $\mathrm{L}^{*}$ value). However, body weight and back fat thickness were not influenced by the crude fat contents in this study. The chemical composition, including crude fat contents, was not related to the coat color.

Korean meat consumers have a unique patterns of meat consumption. Most consumers prefer meats containing a higher percentage of fat, such as belly or chuck roll, than lean meats. This differs from the Chinese, Japanese and western countries. Moreover, black pigs, such as KNP or Berkshire, are highly appreciated by Korean consumers because they believe that black pigs have high redness and intramuscular fat content compared with other pig breeds. There are clear differences in the character of KNP meat compared to western breeds such as Yorkshire (Kim et al., 2009). KNP meat color indeed has significantly higher redness and yellowness than that of Yorkshire meat (Kim et al., 2008). Park et al. (2007) reported that the intramuscular fat content and back fat thickness were significantly higher for KNP than the Landrace breed (Park et al., 2007), although their body weight and growth rate are lower than other commercial pig breeds. Conversely, other factors such as water holding capacity and $\mathrm{pH}$ were not significantly different between the two breeds (Kim et al., 2008). These two breeds were selected for opposite reasons: fats and efficient growth in the Yorkshire breed and meat quality for KNP (Kim et al., 2009). In this study we noticed that most meat quality characteristics were not significantly different among the coat color groups of crossbred pigs. These results can be explained that meat quality characteristic may be due to the fact that the pigs of this study were the second generation crossbred $\left(\mathrm{F}_{2}\right)$. Thus, meat quality characteristic may be genetically diluted and mixed by crossbreeding with Landrace.

\section{Histochemical characteristics}

Histochemical characteristics as a muscle fiber types are presented in Figure 2. Muscle fiber types were classified into three fiber types, namely fiber type I, IIA and IIB, according to the nomenclature of Brooke and Kaiser (1970). Muscle fiber diameter and fiber density were not significantly different among the different coat color groups $(p<0.05)$. Fiber number of type IIB was higher in the E group and significantly lower in the B (White) and F (Black spot in red) groups. However, fiber area of type IIB was significantly greater in the B (White) group than those of other coat color groups. Ryu et al. (2005) reported that the fiber number and area percentage were not affected by muscle mass (carcass weight and loin-eye area). However, we found here that fiber number composition and area composition showed to be significantly different with different muscle mass (carcass weight), although type I and type IIA were not significantly different among the different coat color groups and muscle mass. Type IIB fiber is closely related to water-holding capacity (WHC), color, tenderness and $\mathrm{pH}$. An increase of higher type IIB fiber is related to a decreased WHC and an increased toughness (Seiedeman and Crouse, 1986; Karlsson et al., 1993, Ryu and Kim, 2006). Moreover, Park et al. (2007) reported that red muscles are mainly composed of oxidative type I fibers, whereas white muscles are mainly composed of glycolytic
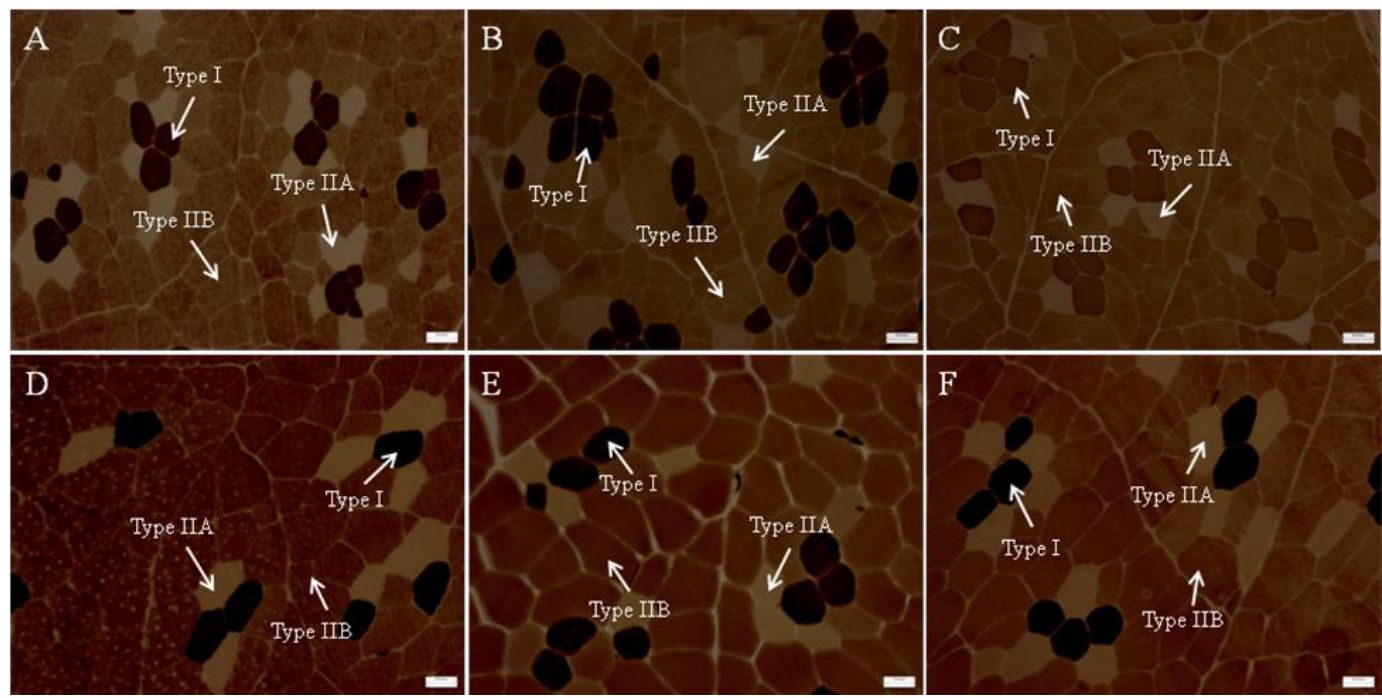

Figure 2. Distribution of muscle fiber types of the longissmus dorsi muscles in crossbred pig (KNP $\times$ Landrace) $\mathrm{F}_{2}$. Serial sections of muscles were stained for myosin ATPase reactivity after preincubation at $\mathrm{pH} 4.65$. Magnification of $100 \times$ was used $(\mathrm{Bar}=50 \mu \mathrm{m})$. A: Black, B: White, C: Red, D: White spot in black, E: Black spot in white, F: Black spot in red. 
Table 3. Blood characteristics of crossbred pigs (KNP $\times$ Landrace) $\mathrm{F}_{2}$

\begin{tabular}{lcccccr}
\hline \multirow{2}{*}{ Measurements } & \multicolumn{5}{c}{ Coat color groups } \\
\cline { 2 - 7 } & $\mathrm{A}^{1}$ & $\mathrm{~B}$ & $\mathrm{C}$ & $\mathrm{D}$ & $\mathrm{E}$ & $\mathrm{F}$ \\
\hline Total protein $(\mathrm{g} / \mathrm{dl})$ & $7.56 \pm 0.89$ & $7.57 \pm 0.54$ & $7.10 \pm 0.69$ & $7.53 \pm 0.70$ & $7.65 \pm 0.87$ & $7.46 \pm 0.80$ \\
Triglyceride $(\mathrm{mg} / \mathrm{dl})$ & $39.80 \pm 3.25$ & $42.32 \pm 2.12$ & $38.60 \pm 1.87$ & $40.00 \pm 3.21$ & $44.91 \pm 4.69$ & $42.91 \pm 5.14$ \\
Cholesterol $(\mathrm{mg} / \mathrm{dl})$ & $97.65 \pm 6.23$ & $97.06 \pm 5.30$ & $90.50 \pm 2.54$ & $101.67 \pm 3.69$ & $101.76 \pm 5.12$ & $97.89 \pm 3.29$ \\
Creatine phosphokinase $(\mathrm{CPK}) \mathrm{mU} / \mathrm{ml}$ & $3,369.39 \pm 250$ & $3,240.78 \pm 356$ & $2,780.00 \pm 120$ & $1,879.41 \pm 351$ & $3,014.67 \pm 657$ & $3,102.95 \pm 701$ \\
White blood cell $\left(10^{3} / \mathrm{mm}^{3}\right)$ & $16.83 \pm 3.21$ & $16.67 \pm 1.38$ & $20.60 \pm 4.12$ & $16.49 \pm 3.78$ & $16.83 \pm 5.12$ & $16.29 \pm 3.70$ \\
Red blood cell $\left(10^{6} / \mathrm{mm}^{3}\right)$ & $8.13 \pm 0.21^{\mathrm{A}}$ & $7.46 \pm 0.35^{\mathrm{B}}$ & $7.80 \pm 0.17^{\mathrm{AB}}$ & $8.02 \pm 0.13^{\mathrm{A}}$ & $7.98 \pm 0.30^{\mathrm{A}}$ & $7.77 \pm 0.27^{\mathrm{AB}}$ \\
Hemoglobin $(\mathrm{g} / \mathrm{dl})$ & $12.94 \pm 1.03$ & $12.61 \pm 2.54$ & $12.28 \pm 1.87$ & $12.21 \pm 3.20$ & $13.01 \pm 0.87$ & $13.32 \pm 1.28$ \\
Globulin $(\mathrm{g} / \mathrm{dl})$ & $3.22 \pm 0.56$ & $3.21 \pm 0.27$ & $2.80 \pm 0.92$ & $3.10 \pm 0.53$ & $3.32 \pm 0.14$ & $3.11 \pm 0.30$ \\
\hline
\end{tabular}

${ }_{\mathrm{A}, \mathrm{B}}$ Means $( \pm \mathrm{SD})$ with different letters are significantly different $(\mathrm{p}<0.05)$.

${ }^{1}$ A: Black coat color, B: White coat color, C: Red coat color, D: White spot in black coat color, E: Black spot in white coat color, F: Black spot in red coat color. $\mathrm{N}=580$.

type IIB fibers. Our results indicated that the changes of both fiber number and fiber area of type IIB did not influenced the WHC, color or shear force in any of the coat groups.

\section{Blood characteristics}

The blood characteristics are presented in Table 3. Most blood characteristics were not significantly different among the different coat color groups, except red blood cells. Red blood cell count was significantly higher in group D (white spot in black coat color) and E (black spot in white coat color) than in other groups. In general, red blood cells contain the hemoglobin molecule. It has a marked effect on meat color because hemoglobin has the ability to bind with several chemical compounds, including oxygen, water and nitrite. We found that, red blood cells were significantly different among the different coat color groups. Interestingly, though, the difference of red blood cell did not influenced meat color. Moreover, blood lipids, such triglyceride and cholesterol, also were not significantly different among the different groups. This indicates that blood characteristics do not influenced meat quality and carcass characteristics in different coat color groups of crossbred pigs.

\section{Final remarks}

As mentioned above, Korean meat consumers prefer black coat color pigs to white coat color pigs, and the reddish meat of KNP with higher intramuscular fat content is the most important factors to the Korean consumer. However, we observed that coat color of crossbred pigs F2 (Korean native pig $\times$ Landrace) is not related to the meat

Table 4. Histochemical characteristics of crossbred pigs $\left(\mathrm{KNP} \times\right.$ Landrace) $\mathrm{F}_{2}$

\begin{tabular}{|c|c|c|c|c|c|c|}
\hline \multirow{2}{*}{ Measurements } & \multicolumn{6}{|c|}{ Coat color groups } \\
\hline & $\mathrm{A}^{1}$ & $\mathrm{~B}$ & $\mathrm{C}$ & $\mathrm{D}$ & $\mathrm{E}$ & $\mathrm{F}$ \\
\hline \multicolumn{7}{|c|}{ Fiber number composition (\%) } \\
\hline Type I & $12.01 \pm 3.12$ & $12.96 \pm 2.69$ & $11.59 \pm 4.14$ & $7.58 \pm 2.45$ & $8.06 \pm 3.08$ & $14.36 \pm 1.69$ \\
\hline Type IIA & $10.02 \pm 3.45$ & $12.00 \pm 2.56$ & $11.73 \pm 3.87$ & $8.86 \pm 6.24$ & $4.83 \pm 3.89$ & $9.85 \pm 5.78$ \\
\hline Type IIB & $77.97 \pm 0.77^{\mathrm{BC}}$ & $75.04 \pm 0.23^{\mathrm{C}}$ & $76.68 \pm 0.56^{\mathrm{BC}}$ & $83.57 \pm 0.63^{\mathrm{AB}}$ & $87.11 \pm 0.54^{\mathrm{A}}$ & $75.79 \pm 0.47^{\mathrm{C}}$ \\
\hline \multicolumn{7}{|c|}{ Fiber area composition $(\%)$} \\
\hline Type I & $11.11 \pm 3.56$ & $15.07 \pm 4.68$ & $9.06 \pm 2.17$ & $8.87 \pm 4.32$ & $7.33 \pm 2.56$ & $9.01 \pm 3.25$ \\
\hline Type IIA & $6.82 \pm 3.21$ & $14.41 \pm 2.36$ & $7.40 \pm 4.21$ & $9.77 \pm 1.87$ & $5.25 \pm 2.65$ & $6.43 \pm 3.47$ \\
\hline Type IIB & $82.07 \pm 0.89^{\mathrm{A}}$ & $70.52 \pm 1.01^{\text {В }}$ & $83.54 \pm 1.23^{\mathrm{A}}$ & $81.35 \pm 0.97^{\mathrm{A}}$ & $87.42 \pm 0.84^{\mathrm{A}}$ & $84.55 \pm 1.03^{\mathrm{A}}$ \\
\hline \multicolumn{7}{|c|}{ Fiber diameter $(\mu \mathrm{m})$} \\
\hline Type I & $67.14 \pm 2.36$ & $71.78 \pm 3.65$ & $70.21 \pm 4.56$ & $72.00 \pm 3.57$ & $66.14 \pm 2.48$ & $63.75 \pm 4.57$ \\
\hline Type IIA & $64.39 \pm 3.56$ & $73.82 \pm 2.74$ & $66.98 \pm 1.08$ & $70.22 \pm 2.36$ & $73.77 \pm 3.14$ & $63.60 \pm 6.02$ \\
\hline Type IIB & $72.14 \pm 1.78$ & $60.32 \pm 4.69$ & $83.37 \pm 4.75$ & $62.41 \pm 6.10$ & $67.30 \pm 3.04$ & $84.26 \pm 4.08$ \\
\hline \multicolumn{7}{|c|}{ Fiber density (number/mm²) } \\
\hline Type I & $26.77 \pm 2.13$ & $34.42 \pm 1.18$ & $19.31 \pm 2.31$ & $19.99 \pm 3.65$ & $20.82 \pm 2.21$ & $27.37 \pm 3.14$ \\
\hline Type IIA & $21.30 \pm 3.23$ & $32.66 \pm 2.36$ & $20.92 \pm 3.64$ & $23.23 \pm 2.31$ & $11.36 \pm 3.12$ & $16.21 \pm 1.01$ \\
\hline Type IIB & $171.75 \pm 3.69$ & $200.44 \pm 4.56$ & $131.50 \pm 10.30$ & $221.85 \pm 9.02$ & $228.04 \pm 6.28$ & $143.67 \pm 4.78$ \\
\hline
\end{tabular}

$\overline{\mathrm{A}, \mathrm{B}, \mathrm{C}}$ Means $( \pm \mathrm{SD})$ with different letters are significantly different $(\mathrm{p}<0.05)$.

${ }^{1}$ A: Black coat color, B: White coat color, C: Red coat color, D: White spot in black coat color, E: Black spot in white coat color, F: Black spot in red coat color. $\mathrm{N}=90$. 
quality characteristics and blood parameters although body weights varied among the coat groups. Therefore, judging from the point of view of meat quality and not from consumer acceptability and willingness to purchase, we can assume that genetic breeding, aiming to develop black coat color pigs, may be not necessary.

\section{ACKNOWLEDGEMENTS}

This paper was supported by the SMART Research Professor Program of Konkuk University.

\section{REFERENCES}

AOAC. 1995. Official methods of analysis, Sec. 950.46 A. Association of Office Analytical Chemists, Arlington, Virginia, USA.

Brooke, M. H., and K. K. Kaiser. 1970. Three myosin adenosine triphosphatase system: the nature of their $\mathrm{pH}$ liability and sulphydryl dependence. J. Histochem. Cytochem. 18:670-672.

Cho, S. H., B. Y. Park, J. H. Kim, M. J. Kim, P. N. Seong, Y. J. Kim, and D. H. Kim. 2007. Carcass yields and meat quality by live weight of Korean Native Black pigs. J. Anim. Sci. Technol. 49:523-530.

Cisneros, F., M. Ellis, F. K. McKeith, J. McGraw, and R. L. Fernando. 1996. Influence of slaughter weight on growth and carcass characteristics, commercial cutting and curing yields, and meat quality of barrows and gilts from two genotypes. J. Anim. Sci. 74:925-933.

Correa, J. A., L. Faucitano, J. P. Laforest, J. Rivest, M. Marcoux, and C. Gariepy. 2006. Effect of slaughter weight on carcass composition and meat quality in pigs of two different growth rates. Meat Sci. 72:91-99.

de Koning, D. J., L. L. G. Janss, A. P. Rattink, P. A. M. van Oers, B. J. de Vries, M. A. M. Groenen, J. J. van der Poel, P. N. de Groot, E. W. Brascamp, and J. A. M. van Arendonk. 1999. Detection of quantitative trait loci for backfat thickness and intramuscular fat content in pigs (Sus scrofa). Genetics 152:1679-1690.

Dubowitz, V., and M. H. Brooke. 1973. Muscle biopsy: A modern approach. W. B. Saunders, London.

Folch, J., M. Lees, and G. H. Sloane-Stanley. 1957. A simple method for the isolation and purification of total lipids from animal tissues. J. Biol. Chem. 226:497-509.

Galián, M., A. Poto, and P. Peinado. 2009. Carcass and meat quality traits of the Chato Murciano pig slaughtered at different weights. Livest. Sci. 124:314-320.

Han, S. H., K. Y. Shin, S. S. Lee, M. S. Ko, D. K. Jeong, J. T. Jeon, and I. C. Cho. 2008. Effects of ADCYP1R1, FABP3, FABP4, MC4R, MYL2 genotypes on growth traits in $F_{2}$ population between Landrace and Jeju native black pig. J. Anim. Sci. Technol. 50:621-632.
Huff, E. J., and F. C. Parrish Jr. 1993. Bovine longissimus muscle tenderness as affected by post-mortem aging time, animal age and sex. J. Food Sci. 58:713-716.

Jeon, J. T., E. W. Park, H. J. Jeon, T. H. Kim, K. T. Lee, and I. C. Cheong. 2003. A large-insert porcine library with sevenfold genome coverage: a tool for positional cloning of candidate genes for major quantitative traits. Mol. Cells 16:113-116.

Karlsson, A., A. C. Enflat, B. Essen-gustavsson, K. Lundstrom, L. Rydhmer, and S. Stern. 1993. Muscle histochemical and biochemical properties in relation to meat quality during selection for increased lean tissue growth rat in pigs. J. Anim. Sci. 71:930-938.

Kim, K. S., J. S. Yeo, and J. W. Kim. 2002. Assessment of genetic diversity of Korean native pig (Sus scrofa) using AFLP markers. Genes Genet. Syst. 77:361-368.

Kim, N. K., J. H. Lim, M. J. Song, O. H. Kim, B. Y. Park, M. J. Kim, I. H. Hwang, and C. S. Lee. 2008. Comparisons of longissimus muscle metabolic enzymes and muscle fiber types in Korean and western pig breeds. Meat Sci. 78:455-460.

Kim, S. S., J. R. Kim, J. K. Moon, B. W. Choi, T. H. Kim, K. S. Kim, J. J. Kim, and C. K. Lee. 2009. Transcriptional alteration of p53 related processes as a key factor for skeletal muscle characteristics in Sus scrofa. Mol. Cells 28:565-573.

Kim, T. H., K. S. Kim, B. H. Choi, D. H. Yoon, G. W. Jang, K. T. Lee, H. Y. Chung, H. Y. Lee, H. S. Park, and J. W. Lee. 2005. Genetic structure of pig breeds from Korea and China using microsatellite loci analysis. J. Anim. Sci. 83:2255-2263.

Latorre, M. A., R. La'zaro, D. G. Valencia, P. Medel, and G. G. Mateos. 2004. The effects of sex and slaughter weight on the growth performance, carcass traits, and meat quality characteristics of heavy pigs. J. Anim. Sci. 82:526-533.

Park, B. Y., N. K. Kim, C. S. Lee, and I. H. Hwang. 2007. Effect of fiber type on postmortem proteolysis in longissimus muscle of Landrace and Korean native black pigs. Meat Sci. 77:482491

Piao, J. R., J. Z. Tian, B. G. Kim, Y. I. Choi, Y. Y. Kim, and I. K. Han. 2004. Effects of sex and market weight on growth performance carcass characteristics and pork quality of market hogs. Asian-Aus. J. Anim. Sci. 17:1452-1458.

Ryu, Y. C., and B. C. Kim. 2005. The relationship between muscle fiber characteristics, postmortem metabolic rate, and meat quality of pig longissimus dorsi muscle. Meat Sci. 71:351-357.

Ryu, Y. C., and B. C. Kim. 2006. Comparison of histochemical characteristics in various pork groups categorized by postmortem metabolic rate and pork quality. J. Anim. Sci. 84:894-901.

SAS. 2002. SAS/STAT Software for PC. SAS Institute Inc., Cary, NC, USA.

Sanudo, C., E. S. Macie, J. L. Olleta, M. Villarroel, B. Panea, and P. Alberti. 2004. The effects of slaughter weight, breed type and ageing time on beef meat quality using two different texture devices. Meat Sci. 66:925-932.

Seiedeman, S. C., and J. D. Crouse. 1986. The effects of sex condition, genotype and diet on bovine muscle fiber characteristics. Meat Sci. 17:55-72. 